\title{
P276: Impact of nosocomial infection prevention program at departmental hospital center of Zou Collines, Benin
}

\author{
TA Ahoyo*, JM Agoi, A Attolou Gbohoun
}

From 2nd International Conference on Prevention and Infection Control (ICPIC 2013)

Geneva, Switzerland. 25-28 June 2013

\section{Objectives}

The study was performed to determine the impact of hygiene measure promotion on the frequency of nosocomial infection (NI).

\section{Methods}

From April 2004 for a period of six years (2004-2010), we conducted an annual one day prevalence study of NI, preceded by a campaign of hygiene measure promotion. In the absence of national NI definition, we used the protocol drawn up in 2002 by CLIN Sud-Ouest (France). Patient's characteristics were recorded and data collection was performed by nurses who had been trained. Quick audit was applied to assess the hand hygiene compliance.

\section{Results}

For the six year period 484, 629, 688, 750, 780, 1115 patients were included, resulting in a prevalence of NI of $41 \%, 31 \%, 22 \%, 18 \%, 13 \%$, and $13 \%$ in 2004 to 2010 respectively, corresponding in absolute reduction of $28 \%$ of IN $\left(\mathrm{p}<10^{-5}\right)$. Compliance of hand hygiene was respectively $23 \%, 43 \%, 45 \%, 47 \%, 53 \%, 55 \%$. The increase of hand disinfection of $30 \%\left(\mathrm{p}<10^{-5}\right)$ was noticed because of the use of alcohol solution. The demographics data were almost identical in all six year. Urinary infections were the most prevalent; a reduction of $15 \%$ was noticed among infection related to catheter.

\section{Conclusion}

These findings suggest that hand washing should become an educational priority in our context of limited budgets; appropriate allocution of resources is needed.

Health Minstry of Benin, Cotonou, Benin

\author{
Competing interests \\ None declared.
}

Published: 20 June 2013

Submit your next manuscript to BioMed Central and take full advantage of:

- Convenient online submission

- Thorough peer review

- No space constraints or color figure charges

- Immediate publication on acceptance

- Inclusion in PubMed, CAS, Scopus and Google Scholar

- Research which is freely available for redistribution 